\section{Transformational leadership and employee voice for product and process innovation in SMEs}

\section{Product and process innovation in SMEs}

\author{
Muhammad Athar Rasheed and Khuram Shahzad
}

School of Business and Economics, University of Management and Technology, Lahore, Pakistan, and

Sajid Nadeem

Faculty of Business and Economics, University of Kassel, Kassel, Germany and Department of Business Administration, Faculty of Management Sciences, ILMA University, Karachi, Pakistan
Received 17 January 2020 Revised 3 April 2020 30 August 2020 Accepted 2 September 2020

\begin{abstract}
Purpose - This study aims to investigate the impact of transformational leadership on the innovation of small and medium enterprises (SMEs) through employee voice behaviors. Drawing from the upper echelon theory, it is hypothesized that employee voice is the mediating mechanism through which transformational leadership affects the process and product innovation in SMEs.

Design/methodology/approach - Data was collected from 169 SMEs of Pakistan through an online self-administered questionnaire. The proposed hypotheses were tested using partial least squares structural equation modeling (PLS-SEM).

Findings - Findings confirm that transformational leadership positively affects both process and product innovation in SMEs and employee voice behavior mediates between these relationships.

Originality/value - This research contributes to both theoretical and practical domains by providing evidence that encouraging employees to raise their voice positively impacts product and process innovation and transformational leadership is a potential organizational factor to shape employee voice and process and product innovation. To the best knowledge, this is the first study that investigates the mediating role of employee voice between transformational leadership and process and product innovation in SMEs and developing country's context.
\end{abstract}

Keywords Pakistan, Transformational leadership, Employee voice, Process innovation, Small and medium enterprises (SMEs), Product innovation

Paper type Research paper

\section{Introduction}

Innovation over time has emerged as a critical factor for the survival, growth and competitive advantage of small and medium enterprises (SMEs) (Chatzoglou \& Chatzoudes, 2018; Dunne, Aaron, McDowell, Urban, \& Geho, 2016; Jiang \& Chen, 2018). Innovation can be broadly defined as "the adoption of an idea or behavior, whether a system, policy,

(C) Muhammad Athar Rasheed, Khuram Shahzad, Sajid Nadeem. Published in Innovation and Management Review. Published by Emerald Publishing Limited. This article is published under the Creative Commons Attribution (CC BY 4.0) licence. Anyone may reproduce, distribute, translate and create derivative works of this article (for both commercial and non-commercial purposes), subject to full attribution to the original publication and authors. The full terms of this licence may be seen at http://creativecommons.org/licences/by/4.0/legalcode

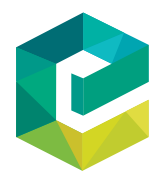

Innovation \& Management Review Vol. 18 No. 1, 2021 pp. $69-89$

pp. $69-8$
Emerald Publishing Limited 2515-8961 
INMR 18,1

program, device, process, product or service, that is new to the adopting organization" (Jiménez-Jiménez \& Sanz-Valle, 2008, p. 1209). SMEs operate with limited resources and their ability to adopt new technologies and introduce new products and services enables them to compete successfully in the marketplace (Hervas-Oliver, Sempere-Ripoll, \& BoronatMoll, 2014; Love \& Roper, 2015; Siqueira and Cosh, 2008).

Scholars assert that SMEs' innovation is associated with leadership behaviors (Corsi \& Prencipe, 2018; Cortes \& Herrmann, 2019; Dunne, Aaron, McDowell, Urban, \& Geho, 2016), which the literature predominantly points to transformational leadership (TL) - a specific pattern of behavior through which leaders can uplift organizational innovation (Gumusluoğlu \& Ilsev, 2009; Jiang \& Chen, 2018). TL uses inspirational motivation, intellectual stimulation and individualized consideration (Bass \& Riggio, 2006) to inspire, empower and motivate employees to exhibit higher learning, self-initiatives, knowledge sharing and ideas development, which leads to innovation (Al-Husseini \& Dosa, 2016; Molodchik, Jardon, \& Yachmeneva., 2020).

Though the literature provides ample evidence for the positive relationship between TL and innovation, there is little empirical research available on SMEs in developing countries' contexts. This is the first gap this study intends to address by investigating the effect of TL on innovation outcomes of SMEs in a developing country's context, i.e. Pakistan. SMEs are different from large firms and the dynamics of leadership may work differently for innovation in such firms considering their small, flexible and adaptive social and organizational structure (Matzler, Schwarz, Deutinger, \& Harms, 2008). Similarly, developing countries differ from developed countries (Hofstede, 1984) in terms of their cultural and management practices which can potentially influence the way leadership styles are implemented by the organizations and perceived and inspired by the followers.

On the other hand, the contemporary debates in leadership and innovation literature remain regarding the mechanism through which TL is associated with innovation. Though studies have identified few mediating factors such as organizational support and empowerment (Jung, Chow, \& Wu, 2003), follower's creativity (Gumusluoğlu \& Ilsev, 2009), social capital (Cortes \& Herrmann, 2019) and organizational learning and culture (Fernandes, Vasconcelos, \& Dobelin, 2018; Sethibe, 2018; Tipu, Ryan, \& Fantazy, 2012), the literature is still theoretically undeveloped in terms of specifying employee behaviors that facilitate TL to shape innovation. Despite the findings that organizational leadership shapes employee pro-innovative behaviors (Knezović \& Drkić, 2020), which, in turn, facilitate innovation outcomes in SMEs (McDowell, Peake, Coder, \& Harris, 2018), there is little knowledge available as to how these variables interact in SMEs of developing countries to influence organization innovation. Scholars, therefore, call for further investigations to unveil promising behavioral mechanisms underlying TL's effect on innovation outcomes (Cortes \& Herrmann, 2019; Fernandes, Vasconcelos, \& Dobelin, 2018).

Consequently, we propose that employee "voice" behavior is a potential mechanism through which TL may influence desired innovation outcomes in SMEs. Employee voice is referred to:

[...] the discretionary or formal expression of ideas, opinions, suggestions or alternate approaches directed to a specific target inside or outside of the organization with the intent to change an objectionable state of affairs and to improve the current functioning of the organization, group or individual (Bashshur \& Oc, 2015, p. 1531).

Employee voice has been identified as a significant determinant of creativity and innovation at the individual, group and organizational levels (Bashshur \& Oc, 2015; Selvaraj \& Joseph, 2020). The study of employee voice concerning TL is particularly relevant for SMEs as the 
small size and relational orientation of these firms enable leadership to inspire and motivate employees to exhibit innovative behaviors (Matzler, Schwarz, Deutinger, \& Harms, 2008). TL motivates employees to participate in decision-making and take initiatives to implement creative ideas and correct problems that inhibit organizations from learning and innovating. However, despite the critical role of employee voice in innovation for all types of organizations, the concept remains under-theorized and under-researched in SMEs (Gilman, Raby, \& Pyman, 2015; Sameer \& Özbilgin, 2014). Furthermore, there is a dearth of research on employee voice in developing countries' contexts (Wilkinson, Mowbray, \& Sun, 2018). Therefore, while addressing this gap and recent calls, we argue that employee voice is a potential mechanism through which TL can influence innovation outcomes in SMEs.

Given this, the current study contributes to leadership and innovation literature by conceptualizing employee voice as a potential mediating mechanism between the relationship of TL and innovation outcomes. Furthermore, this study enriches the literature with the understanding of SMEs and developing country's contexts that have been largely ignored by past scholars.

\section{Literature review and hypotheses development}

We draw from the upper echelon theory to propose that TL affects process and product innovation in SMEs through employee voice. Upper echelon theory assumes that the organization is a true reflection of its top leadership, which shapes its strategic and operational processes and outcomes (Hambrick \& Mason, 1984). The theory further asserts that leadership shapes up employee behaviors consistent with the organization's strategic direction and intended performance goals. In the SME context, upper echelon theory is considered particularly relevant as it explains how an owner or entrepreneur-led organization develops its processes and employee behaviors consistent with top management's strategic orientation and desired goals. In this study, the theoretical lens offered by upper echelon theory is used to conceptualize the role of TL in shaping employee voice behaviors and innovation in SMEs.

\section{Process and product innovation}

Innovation can be defined as the adoption of a new idea, program, system, process, service or product (Jiménez-Jiménez \& Sanz-Valle, 2008). The literature primarily segregates innovation into three distinct dimensions, i.e. product innovation, process innovation and business model or management innovation (Snihur \& Wiklund, 2019). Though all these innovation forms contribute significantly to organizational success, scholars have found product and process innovation (Chang, Bai, \& Li, 2015) as the most crucial forms of innovation to secure competitive advantage for SMEs (Murat \& Baki, 2011). However, despite the importance of these innovation forms, the extant literature has mainly focused on product or service innovation (Atuahene-Gima, 1995; Zhou \& Wu, 2010), and thus little attention has been paid to process innovation (Chang, Bai, \& Li, 2015; Damanpour \& Gopalakrishnan, 2001). Therefore, in this study, we adopt a comprehensive approach and measure both product and process innovation as separate outcomes of TL and employee voice.

Product innovation is defined as the development and introduction of new products or services into the marketplace to satisfy customers' needs and wants (Jiménez-Jiménez \& Sanz-Valle, 2008). Process innovation, on the other hand, is viewed as the new ways and activities adopted or introduced into the production and delivery of products or services (Jiménez-Jiménez \& Sanz-Valle, 2008), e.g. information flow and service delivery 
INMR

18,1

mechanisms, tasks specifications, input materials and equipment for successful production of the product or render a service (Damanpour \& Gopalakrishnan, 2001; Ettlie \& Reza, 1992).

Product innovation is vital for the growth and sustainability of SMEs as these firms do not possess enough resources to match large organizations' investments in distribution and marketing channels. SMEs rely on innovative products and services instead of looking for mass production to achieve cost advantage (Tarigan, 2018). Process innovation, on the other hand, enables SMEs to improve their product development life cycle and production and delivery of goods in a cost-effective manner (Hervas-Oliver, Sempere-Ripoll, \& Boronat-Moll, 2014). While product innovation relates to differentiation strategy, process innovation is considered important to achieve production efficiency-based cost advantage (Barney, Wright, \& Ketchen, 2001; Porter, 1990). Though literature defines product and process innovation separately based on varying form and magnitude and SMEs may differ in their focus on any specific innovation, a firm's competitive advantage depends on the synergistic complementarity of both innovation types (Chang, Bai, \& Li, 2015; Damanpour \& Gopalakrishnan, 2001; Hullova, Trott, \& Simms, 2016).

\section{Voice}

Voice is defined as "the discretionary or formal expression of ideas, opinions, suggestions or alternate approaches directed to a specific target inside or outside of the organization with the intent to change an objectionable state of affairs and to improve the current functioning of the organization, group or individual" (Bashshur \& Oc, 2015, p. 1531). There is a consensus in the literature that voice is a problem-solving, change-oriented and improvement-seeking behavior such as speaking up, whistleblowing that contributes to several positive outcomes including innovation in the organization (Gilman, Raby, \& Pyman, 2015). However, the voice should not be taken as a granted behavior because due to its change-orientation it challenges the status quo which may bring resistance and negative consequences to those who voice (Gilman, Raby, \& Pyman, 2015). Therefore, organizations need to make concentrated efforts to develop conducive mechanisms and encourage employees to engage in voice behaviors (Harney \& Dundon, 2006; Wilkinson \& Fay, 2011).

The literature notes that SMEs naturally contain more fertile conditions for voice to exist and nurture. For instance, due to relational and less bureaucratic organizational structure and culture, employees in SMEs enjoy more autonomy and opportunity to influence top management (Forth, Bewley, \& Bryson, 2006; Gilman, Raby, \& Pyman, 2015; Wilkinson, Dundon, \& Grugulis, 2007). Therefore, SMEs can take more advantage of voice to achieve its established positive outcomes. However, voice is an under-theorized and under-researched concept in the SME context (Gilman, Raby, \& Pyman, 2015; Sameer \& Özbilgin, 2014).

\section{Transformational leadership}

Transformational leadership (TL) encompasses five key characteristics, namely; vision, inspirational communication, supportive leadership, intellectual stimulation and personal recognition (Rafferty \& Griffin, 2004). The vision is explained as "the expression of an idealized picture of the future based around organizational values." Inspirational communication refers to "the expression of positive and encouraging messages about the organization and statements that build motivation and confidence" (Rafferty \& Griffin, 2004, p. 332). Supportive leadership includes "expressing concern for followers and taking account of their individual needs," and intellectual stimulation means "enhancing employees' interests in and awareness of problems and increasing their ability to think about problems in new ways" (Rafferty \& Griffin, 2004, p. 333). Finally, personal recognition 
refers to "the provision of rewards such as praise and acknowledgment of effort for the achievement of specified goals” (Rafferty \& Griffin, 2004, p. 334).

TL inspires followers with their vision and motivates them with recognition, autonomy and support to think for the larger interests of the organization and perform beyond expectations (Sameer \& Özbilgin, 2014). TL indulges the organization and its members in critical and out-of-box thinking and plays an important role in bringing positive change and innovation to the organization. TL has been identified as an effective organizational tool for promoting employee extra-role behaviors (MacKenzie, Podsakoff, \& Rich, 2001) and organization innovation (Gumusluoglu \& Ilsev, 2009).

TL is particularly relevant for SMEs' context (Hervas-Oliver, Sempere-Ripoll, \& BoronatMoll, 2014). SMEs are dominated mainly by top leadership, which is mostly comprising owners or entrepreneurs who provide strategic and operational vision and direction to the organization and its members (Baum, Locke, \& Smith, 2001). Due to the relatively small firm size, leaders communicate their expectations personally to all employees during which their charisma and inspirational style play a vital role to effectively boost the intrinsic motivation of employees, making it a specifically effective tool in the SME context.

\section{Transformational leadership and product innovation}

The upper echelon theory explains that the top management characteristics have a strong influence on the formation and implementation of strategies to achieve growth and sustainability (Hambrick, 2007). Accordingly, we suggest that TL positively influences the product innovation of SMEs. SMEs owners/managers, due to their ownership stake, have more decision-making authority (Willard, Krueger, \& Feeser, 1992) and a flat organizational structure, which enables them to influence all strategic and operational spheres of the firm.

TL formulates and implements a shared vision that portrays an organization's innovation-based competitive positioning (García-Morales, Llorens-Montes, \& Verdú-Jover, 2006; Hitt, Keats, \& DeMarie, 1998). Further, it invites ideas and suggestions to improve customer experience through innovative solutions in the form of products and services (Lowe, Kroeck, \& Sivasubramaniam, 1996).

Inspirational communication helps organizational members understand strategic choices and the need to develop and introduce innovative solutions for the market to ensure survival and competitiveness (Molodchik, Jardon, \& Yachmeneva., 2020; Stock \& Schnarr, 2016).

Transformational leaders support followers to explore and exploit opportunities to improve or develop products to exceed customers' expectations (Stock and Schnarr, 2016). They boost employees' interest through intellectual stimulation (Lowe, Kroeck, \& Sivasubramaniam, 1996; Rafferty \& Griffin, 2004) and develop their innovative capabilities and behaviors (Cortes \& Herrmann, 2019). Transformational leaders recognize and acknowledge the efforts of their followers and reward them against their achievements (Rafferty \& Griffin, 2004). Hence, the provision of rewards like pay increases and performance-based promotions motivate employees to achieve innovative goals (Rasheed, Shahzad, Conroy, Nadeem, \& Siddique, 2017). The findings of empirical studies suggest that TL is positively associated with product innovation (Back \& Bausch, 2018; Matzler, Schwarz, Deutinger, \& Harms, 2008; Stock \& Schnarr, 2016).

Considering the aforementioned theoretical and empirical arguments, we hypothesize that:

H1. Transformational Leadership will have a positive impact on product innovation in SMEs. 
INMR

18,1

\section{Transformational leadership and process innovation}

Scholars assert that process innovation is one of the prime strategies for SMEs to boost their innovation and performance (Hervas-Oliver, Sempere-Ripoll, \& Boronat-Moll, 2014). However, very limited research has explored its antecedents in SMEs (Hervas-Oliver, Sempere-Ripoll, \& Boronat-Moll, 2014; Keupp, Palmié, \& Gassmann, 2012). We argue that $\mathrm{TL}$ is positively associated with process innovation in SMEs.

The upper echelon theory explains how TL can play an important role in the adoption and implementation of new technologies and processes in SMEs. Due to the flat structure and limited financial and human resources, SMEs heavily rely on the top management's knowledge as compared to research and development (R\&D) to improve the efficiency (Dunne, Aaron, McDowell, Urban, \& Geho, 2016; Molodchik, Jardon, \& Yachmeneva., 2020). Thus, the market knowledge and vision of TL provide directions to employees about the changing technologies and customer needs. TL also communicates its expectations from employees to improve the production and delivery process, reduce cost and enhance supply chain responsiveness which together results in process innovation (Cortes \& Herrmann, 2019; Hervas-Oliver, Sempere-Ripoll, \& Boronat-Moll, 2014; Sattayaraksa \& Boon-itt, 2016).

For process innovation, SMEs need to learn advanced technologies and production methods. By communicating a vision of innovation, transformational leaders can inspire and motivate employees to foster technological innovation (Liaw, Chi, \& Chuang, 2010). Transformational leader's intellectual stimulation and supportive behavior enhance employees' interest and ability to think of new ways to solve complex technological problems (Rafferty \& Griffin, 2004). Innovation requires consistent reflection and learning from employees which leaders promote through empowerment, encouragement and trust (García-Morales, Llorens-Montes, \& Verdú-Jover, 2007; Sattayaraksa \& Boon-itt, 2016) which enable employees to share knowledge to improve the product development process and introduce innovative but cost-efficient methods (Al-Husseini \& Dosa, 2016) for the development and delivery of new products and services (March-Chordà, Gunasekaran, \& Lloria-Aramburo, 2002).

The empirical evidence suggests that TL contributes positively to process innovation or a new product development process (Al-Husseini \& Dosa, 2016; Sattayaraksa \& Boon-itt, 2016). Therefore, we hypothesize that:

H2. Transformational leadership will have a positive impact on process innovation in SMEs.

\section{Mediating role of voice}

Prior literature suggests that leadership style plays an important role in the process and product innovation of organizations. However, there is little research explaining the mechanisms through which TL influences innovation (Back \& Bausch, 2018; Stock \& Schnarr, 2016), particularly in SMEs (Cortes and Herrmann, 2019). We suggest that employee voice behavior serves as a potential mediating mechanism to explain the impact of TL on the process and product innovation in SMEs.

TL may generate pro-innovation voice behaviors by supporting and encouraging employees to challenge the status quo and provide constructive suggestions (Schmitt, Den Hartog, \& Belschak, 2016) to make improvements in the processes and innovate products and services. A transformational leader can interact and communicate personally with all employees to explain the need and roadmap to innovate processes and products (Svendsen \& Joensson, 2016). They can also develop confidence among employees that their ideas and suggestions will be attended and reflected in the decision-making by the top management. 
The inclusion of ideas and suggestions of employees in the organizational decision-making process enables SMEs to improve or introduce products and services (Sameer \& Özbilgin, 2014). Detert \& Burris (2007) assert that transformational leaders can promote speaking up or whistleblowing behaviors to identify and report practices that hinder organizational innovation. Transformational leader's inspirational communication skills may encourage employees to report errors and provide suggestions for new products confidently. Encouragement from and trust in leadership has been established as an important factor to shape employee voice behaviors and innovation (Chen \& Hou, 2016; Gumusluoglu \& Ilsev, 2009). Thus, leaders can develop employees' psychological safety by ensuring that they will not be blamed if a new or improved process or product developed with their input fails. Transformational leaders can develop voice behaviors among employees by communicating their voice expectations along with expectations of innovative behaviors (Duan, $\mathrm{Li}, \mathrm{Xu}, \&$ $\mathrm{Wu}, 2017)$.

Literature indicates that SMEs can rectify process and product-related problems to improve the quality of products and services or develop the new ones by facilitating voice behaviors (Sameer \& Özbilgin, 2014; Stock \& Schnarr, 2016). Transformational leaders display individualized consideration, i.e. understanding subordinates' concerns and problems and respect their feelings and needs (Avolio \& Bass, 1995) which helps to create a friendly and supportive environment (Rafferty \& Griffin, 2004). In response to this supportive behavior of leaders, subordinates engage in knowledge sharing and supportive behaviors to bring innovative solutions for the processes and products (Molodchik, Jardon, \& Yachmeneva., 2020; Rasheed, Shahzad, Conroy, Nadeem, \& Siddique, 2017). Recognition for innovative ideas and suggestions may motivate employees to share instead of hiding (Gumusluoglu \& Ilsev, 2009) which may lead to the higher innovative capability of SMEs (Rasheed, Shahzad, Conroy, Nadeem, \& Siddique, 2017).

In light of the aforementioned theoretical and empirical arguments, we, therefore, hypothesize that:

H3. Employee voice plays a mediating role between transformational leadership and product innovation.

H4. Employee voice plays a mediating role between transformational leadership and process innovation.

\section{Research methodology}

Sample and data collection process

We collected data from small and medium enterprises (SME) operating all around Pakistan. We adopted the definition of SMEs from the Small and Medium Enterprises Development Authority (SMEDA) which defined SMEs as "the organizations having a maximum of 250 employees or rupees 400 million annual sales turnover in Pakistan's currency" (SMEDA, 2007).

A structured and self-administered questionnaire was distributed online to 800 SMEs listed with SMEDA, chambers of commerce and industry associations of Pakistan. The questionnaire contained information about the survey objective, invitation to participate and the link to the online questionnaire. The survey was supposed to be filled up by heads of department as they were expected to have a better understanding of the top leadership style, voice behaviors and innovation performance in organizations. The response rate of this study is $21.87 \%$, which is consistent with previous research studies conducted in Pakistani SMEs (Rasheed, Shahzad, Conroy, Nadeem, \& Siddique, 2017). In total, we received 175
Product and process innovation in SMEs 
INMR

18,1

responses, out of which six were dropped due to incomplete information, which left the usable sample size to 169 responses.

Our sample comprising SMEs operating for more than nine years $(66 \%)$, between $3-$ 9 years $(22 \%)$ and $1-3$ years $(12 \%)$. In total, $71 \%$ of SMEs were operating in the services sector whereas $29 \%$ were from the manufacturing sector. SMEs using between 100 and 250 people were $39 \%$, between 50 and 100 people were $27 \%$ and $24 \%$ of SMEs used a staff fewer than 50 people. The overall experience of respondents was between 0-2 years $(32.7 \%), 2-$ 5 years $(25.1 \%)$, $5-10$ years $(20.5 \%)$ and more than 10 years $(21.6 \%)$. In total, $93 \%$ of respondents had a minimum of 14 years of qualification with graduation (21.5\%), masters $(51.7 \%)$ and MS/MPhil (21.2\%).

\section{Measures}

We used existing and well-validated scales (Appendix) to measure leadership, voice and innovation constructs. A five-point Likert-type scale was used for all constructs, where $1=$ strongly disagree and $5=$ strongly agree. Higher scores indicate the greater prevalence of the respective factor.

Transformational leadership. TL was measured using 15 items from Rafferty \& Griffin (2004), which included five sub-dimensions, e.g. vision; inspirational communication; intellectual stimulation; supportive leadership; and personal recognition. The Cronbach's alpha of the scale was 0.89 .

Employee voice. A six-item scale was adopted from Dyne \& LePine (1998) to measure the voice behaviors of employees. Cronbach's alpha of the scale was 0.77 .

Product and process innovation. Both product and process innovation were measured using six items from Jiménez-Jiménez \& Sanz-Valle (2008), three items each for process and product innovation. This scale was particularly adopted as the items covered innovation in terms of outputs (e.g. new products or processes), inputs (e.g. R\&D efforts/expenses) and timing (e.g. pioneers, quick second or late followers). The Cronbach's alpha scores of the scales were 0.85 and 0.87 for product and process innovation, respectively.

Control variables. Previous studies highlighted that SME size and age (years of operations) might affect its innovation outcomes (Rasheed, Shahzad, Conroy, Nadeem, \& Siddique, 2017; Shahzad, Arenius, Muller, Rasheed, \& Bajwa, 2019), we included these factors as control variables in our model. We have measured the organization size in terms of the number of employees which was coded as micro (less than 50 employees), small (51100 employees) and medium (101-250 employees). The organization's age was measured as the number of years of operations which was coded as between 1-3 years, 3-9 years and more than 9 years.

\section{Common method bias}

Scholars assert that self-reported data may lead to common-method-bias, which may inflate the results artificially (Podsakoff \& Organ, 1986; Rodríguez-Ardura, Meseguer-Artola, Rodríguez-Ardura, \& Meseguer-Artola, 2020). To address the common-method-bias problem, we followed the guidelines of Podsakoff, MacKenzie, Lee, and Podsakoff (2003) and Rodríguez-Ardura, Meseguer-Artola, Rodríguez-Ardura, and Meseguer-Artola (2020) and used Harman's single-factor test. These authors explained that if a single factor explains less than $50 \%$ of the covariance, it indicates that common-method bias is not affecting results (Podsakoff, MacKenzie, Lee, \& Podsakoff, 2003; Rodríguez-Ardura, MeseguerArtola, Rodríguez-Ardura, \& Meseguer-Artola, 2020). The findings of factor analysis show 
that the single factor explains less than $50 \%$ of the total variance, which confirms that the common-method-bias is not a major concern in this study.

We also checked for non-response bias (Table 1) by comparing late responses with the early ones (Armstrong \& Overton, 1977). The $t$-test of the 50 earliest and 50 latest responses, at a $95 \%$ confidence interval, did not reveal a significant difference. This implies that at $p>0.05$, non-response bias is not a significant issue in this study (Rosca \& Bendul, 2019).

\section{Data analysis and results}

To test our proposed model, we used partial least square structural modeling (PLS-SEM) for constructs validation and structural model assessment using SmartPLS 3.2.3. Scholars suggest that PLS-SEM is a credible statistical approach to test causal mechanisms such as mediation hypotheses (Hair, Risher, Sarstedt, \& Ringle, 2019; Henseler, Ringle, \& Sinkovics, 2009). Hair, Hult, Ringle, and Sarstedt (2014a), Hair, Black, Babin, and Anderson (2014b) explained that PLS-SEM relies on a set of non-parametric evaluation criteria to estimate the results of measurements and structural models. In this study, we followed the step-by-step guidelines provided by Hair, Risher, Sarstedt, \& Ringle (2019) and confirmed the convergent and discriminant validity of constructs before moving on to the hypotheses testing stage.

\section{Measurement model}

We conducted factor analysis by using the PLS algorithm in SmartPLS, which provides factor loadings and cross-loadings. The results in Figure 1 highlight that all the factor loadings were in an acceptable range, i.e. 0.61 to 0.90 (Hair, Hult, Ringle, and Sarstedt, 2014a; Hair, Black, Babin, and Anderson 2014b); after removing six items, i.e. TL1, TL3, TL4, TL9, TL11 and EV5. We deleted these items following the suggestions of Fornell and Larcker (1981) due to poor loadings or problematic significant cross-loading after considering the theoretical rationale. All the remaining items were loaded on their respective constructs with high loading scores which established a valid factor structure of measurement constructs.

To confirm the convergent and discriminant validity of the measurement model, factor loadings, composite reliability (CR) and AVE criteria were used (Hair, Hult, Ringle, and Sarstedt, 2014a; Hair, Black, Babin, and Anderson 2014b). The values of CR ranging from 0.84 to 0.92 in Table 2 highlight that all variables showed good internal consistency (Hair, Risher, Sarstedt, \& Ringle, 2019). The convergent validity is referred to as the extent to which the constructs converge to explain the variance of its items. The convergent validity was assessed through the average variance extracted (AVE) for all items on each construct. The values of AVE $(\mathrm{TL}=0.51$; voice $=0.52$; product innovation $=0.77$; process innovation $=0.79$ ) in Table 2 shows that all constructs explained at least $50 \%$ of the variance of its items which fulfills the minimum benchmark (Fornell \& Larcker, 1981; Hair, Risher, Sarstedt, \& Ringle, 2019).

\begin{tabular}{|c|c|c|c|c|c|c|}
\hline \multirow[b]{2}{*}{ Variable } & \multicolumn{2}{|c|}{ Early 50 responses } & \multicolumn{2}{|c|}{ Late 50 responses } & \multirow[b]{2}{*}{$\begin{array}{l}\text { t-test sig. } \\
\text { (two-tail) }\end{array}$} & \\
\hline & $\begin{array}{l}\text { Mean } \\
\text { score }\end{array}$ & SD & $\begin{array}{l}\text { Mean } \\
\text { score }\end{array}$ & SD & & \\
\hline $\begin{array}{l}\text { Transformational } \\
\text { leadership }\end{array}$ & 349 & & & & & \\
\hline Employee voice & $\begin{array}{l}3.49 \\
3.50\end{array}$ & $\begin{array}{l}0.16 \\
0.62\end{array}$ & $\begin{array}{l}3.60 \\
3.55\end{array}$ & $\begin{array}{l}0.15 \\
0.65\end{array}$ & $\begin{array}{l}0.46 \\
0.68\end{array}$ & Table 1. \\
\hline Product innovation & 3.27 & 0.91 & 3.34 & 0.95 & 0.69 & Non-response bi \\
\hline Process innovation & 3.33 & 0.95 & 3.46 & 0.93 & 0.50 & \\
\hline
\end{tabular}

Product and process innovation in SMEs 
INMR

18,1

78

Figure 1.

The measurement model (outer model)

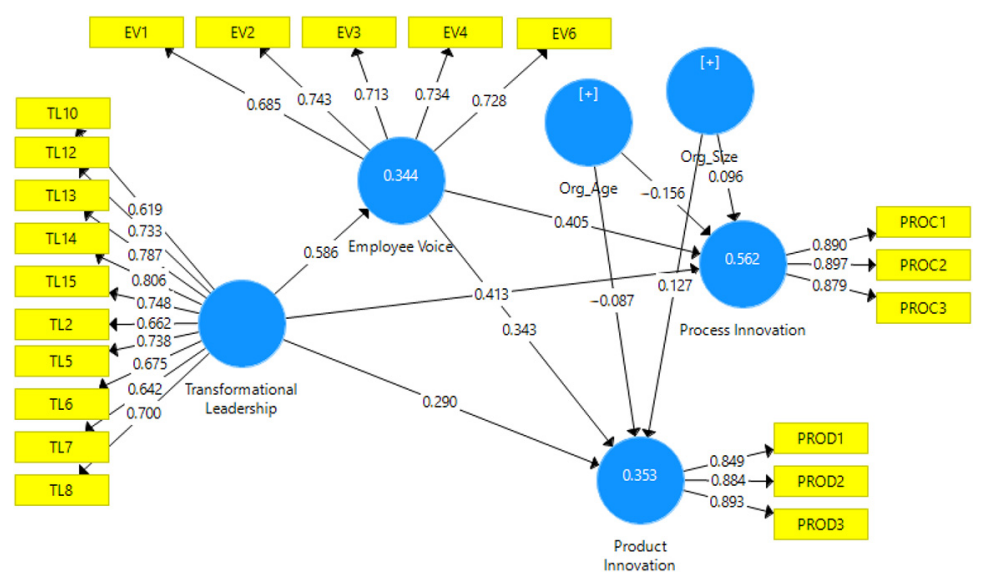

\begin{tabular}{|c|c|c|c|c|c|}
\hline Constructs & Items & Loadings & Cronbach's $\alpha$ & $\mathrm{CR}$ & AVE \\
\hline \multirow{10}{*}{ TL } & TL2 & 0.66 & \multirow[t]{10}{*}{0.89} & \multirow[t]{10}{*}{0.91} & \multirow[t]{10}{*}{0.51} \\
\hline & TL5 & 0.74 & & & \\
\hline & TL6 & 0.68 & & & \\
\hline & TL7 & 0.64 & & & \\
\hline & TL8 & 0.70 & & & \\
\hline & TL10 & 0.62 & & & \\
\hline & TL12 & 0.73 & & & \\
\hline & TL13 & 0.79 & & & \\
\hline & TL14 & 0.81 & & & \\
\hline & TL15 & 0.75 & & & \\
\hline \multirow[t]{5}{*}{ EV } & EV1 & 0.69 & \multirow[t]{5}{*}{0.77} & \multirow[t]{5}{*}{0.84} & \multirow[t]{5}{*}{0.52} \\
\hline & EV2 & 0.74 & & & \\
\hline & EV3 & 0.71 & & & \\
\hline & EV4 & 0.73 & & & \\
\hline & EV6 & 0.73 & & & \\
\hline \multirow[t]{3}{*}{ PROD } & PROD1 & 0.85 & \multirow[t]{3}{*}{0.85} & \multirow[t]{3}{*}{0.91} & \multirow[t]{3}{*}{0.77} \\
\hline & PROD2 & 0.88 & & & \\
\hline & PROD3 & 0.89 & & & \\
\hline \multirow[t]{3}{*}{ PROS } & PROS1 & 0.89 & \multirow[t]{3}{*}{0.87} & \multirow[t]{3}{*}{0.92} & \multirow[t]{3}{*}{0.79} \\
\hline & PROD2 & 0.90 & & & \\
\hline & PROD3 & 0.88 & & & \\
\hline
\end{tabular}

Notes: TL: Transformational leadership, EV: Employee voice, PROD: Product innovation, PROS: Process innovation, CR: Composite reliability, AVE: Average variance extracted

The discriminant validity is referred to as the extent to which a construct is empirically distinct from other constructs in the structural model. To assess and confirm discriminant validity, we followed the suggestions of Fornell and Larcker (1981). They suggest that the AVE of the latent variable should be higher than the squared correlations between the latent variables. The results in Table 3 show that the AVE of the latent variables is higher than the squared correlations between the latent variables, which confirms the discriminant validity (Fornell \& Larcker, 1981). Besides, we confirmed discriminant validity by using the HTMT 
test as Henseler, Ringle, \& Sarstedt (2015) suggest that the HTMT index provides more consistent results. Further, Henseler and colleagues explain that a value $<0.90$ is acceptable for both conceptually different and similar constructs. The results presented in Table 4 confirm discriminant validity as the values of HTMT were less than the recommended threshold level of 0.90 .

\section{Structural model and hypotheses testing}

To assess and draw results, PLS-SEM was used to assess the structural model. PLS-SEM explains the standard assessment criteria to confirm findings, including the coefficient of determination $\left(R^{2}\right)$ and effect size $\mathrm{F}^{2}$ (Hair, Risher, Sarstedt, \& Ringle, 2019). The $R^{2}$ measures the variance, which is explained in each of the endogenous constructs and is, therefore, a measure of the model's explanatory power (Hair, Hult, Ringle, and Sarstedt, 2014a; Hair, Black, Babin, and Anderson, 2014b). The value of $R^{2}$ shows that the model has a moderate coefficient of determination (Hair, Risher, Sarstedt, \& Ringle, 2019; Hair, Hult, Ringle, and Sarstedt, 2014a; 2014b). Hence, in our model (Table 5), TL through employee voice explains $56 \%$ and $35 \%$ of the process and product innovation, respectively. Moreover, the effect size $\left(f^{2}\right)$ was examined, which refers to the contribution of an exogenous variable into $R^{2}$ values of the endogenous variable (Hair, Hult, Ringle, and Sarstedt, 2014a; Hair, Black, Babin, and Anderson, 2014b). Cohen, Manion and Morrison (2013) explained the criteria that effect size is considered as small (0.02); medium (0.15); and large (0.35). The values of $f^{2}$, as presented in Table 5, show the large effect size of TL on employee voice and medium effect on both process and product innovation. However, the effect of employee voice on the process and product innovation is medium. Besides, the $\mathrm{Q}^{2}$ test was used to

\begin{tabular}{lccccccc}
\hline Constructs & EV & Org_age & Org_size & PROS & PROD & TL & AVE \\
\hline Employee voice & 0.72 & & & & & & 0.52 \\
Organization age & 0.10 & 1 & & & & & 1.00 \\
Organization size & 0.15 & 0.30 & 1 & & & & 1.00 \\
Process innovation & 0.65 & -0.07 & 0.18 & 0.89 & & & 0.79 \\
Product innovation & 0.52 & 0.00 & 0.20 & 0.76 & 0.88 & & 0.77 \\
Transformational leadership & 0.59 & 0.05 & 0.18 & 0.66 & 0.51 & 0.71 & 0.51
\end{tabular}

Notes: TL: Transformational leadership, EV: Employee voice, PROD: Product innovation, PROS: Process innovation. Control variables: Org_age: Organization age in years (single item), Org_size: Organization size in terms of employees (single item)

Product and process innovation in SMEs

\section{of} 西 


\begin{tabular}{|c|c|c|c|c|c|c|c|}
\hline INMR & Paths & Path coefficient & $\mathrm{SD}$ & $t$-values & $p$ values & $\mathrm{F}^{2}$ & Hypotheses decision \\
\hline 80 & $\begin{array}{l}\text { Direct effect } \\
\text { TL } \rightarrow \text { PROD } \\
\text { TL } \rightarrow \text { PROC } \\
\text { TL } \rightarrow \text { EV } \\
\text { EV } \rightarrow \text { PROD } \\
\text { EV } \rightarrow \text { PROC } \\
\text { Org_Age } \rightarrow \text { PROD } \\
\text { Org_Age } \rightarrow \text { PROC } \\
\text { Org_Size } \rightarrow \text { PROD } \\
\text { Org_Size } \rightarrow \text { PROC }\end{array}$ & $\begin{array}{r}0.29 \\
0.41 \\
0.59 \\
0.34 \\
0.40 \\
0.13 \\
0.10 \\
-0.09 \\
-0.16\end{array}$ & $\begin{array}{l}0.09 \\
0.08 \\
0.07 \\
0.09 \\
0.08 \\
0.07 \\
0.06 \\
0.06 \\
0.06\end{array}$ & $\begin{array}{l}3.05 \\
4.87 \\
8.75 \\
3.89 \\
5.19 \\
1.88 \\
1.72 \\
1.35 \\
2.58\end{array}$ & $\begin{array}{l}0.00 \\
0.00 \\
0.00 \\
0.00 \\
0.00 \\
0.06 \\
0.09 \\
0.18 \\
0.01\end{array}$ & & $\begin{array}{c}\text { Accepted H1 } \\
\text { Accepted } H 2 \\
- \\
- \\
- \\
- \\
- \\
- \\
-\end{array}$ \\
\hline & $\begin{array}{l}\text { Indirect effect } \\
\mathrm{TL} \rightarrow \mathrm{EV} \rightarrow \mathrm{PROD} \\
\mathrm{EV} \rightarrow \mathrm{EV} \rightarrow \mathrm{PROC}\end{array}$ & $\begin{array}{l}0.20 \\
0.24\end{array}$ & $\begin{array}{l}0.06 \\
0.06\end{array}$ & $\begin{array}{l}3.35 \\
4.10\end{array}$ & $\begin{array}{l}0.00 \\
0.00\end{array}$ & & $\begin{array}{l}\text { Accepted } H 3 \\
\text { Accepted } H 4\end{array}$ \\
\hline & $\begin{array}{l}\text { Total effect } \\
\text { TL } \rightarrow \text { PROD } \\
\text { TL } \rightarrow \text { PROC } \\
\text { TL } \rightarrow \text { EV } \\
\text { EV } \rightarrow \text { PROD } \\
\text { EV } \rightarrow \text { PROC } \\
\text { Org_Age } \rightarrow \text { PROD } \\
\text { Org_Age } \rightarrow \text { PROC } \\
\text { Org_Size } \rightarrow \text { PROD } \\
\text { Org_Size } \rightarrow \text { PROC } \\
R^{2} \text { EV }=0.31 ; R^{2} \text { PRC }\end{array}$ & $\begin{array}{c}0.49 \\
0.65 \\
0.59 \\
0.34 \\
0.40 \\
-0.09 \\
-0.16 \\
0.13 \\
0.10 \\
=0.35 ; R^{2} \mathrm{PROC}\end{array}$ & $\begin{array}{l}0.07 \\
0.05 \\
0.07 \\
0.09 \\
0.08 \\
0.06 \\
0.06 \\
0.07 \\
0.06 \\
.56\end{array}$ & $\begin{array}{r}7.32 \\
12.72 \\
8.85 \\
3.89 \\
5.19 \\
1.35 \\
2.58 \\
1.88 \\
1.72\end{array}$ & $\begin{array}{l}0.00 \\
0.00 \\
0.00 \\
0.00 \\
0.00 \\
0.18 \\
0.01 \\
0.06 \\
0.09\end{array}$ & $\begin{array}{l}0.26 \\
0.17 \\
0.52 \\
0.22 \\
0.22\end{array}$ & $\begin{array}{l}- \\
- \\
- \\
- \\
- \\
- \\
- \\
-\end{array}$ \\
\hline
\end{tabular}

Table 5.

Path analysis and hypotheses testing
Notes: TL: Transformational leadership, EV: Employee voice, PROD: Product innovation, PROS: Process innovation, Org_age: Organization age in years (single item), Org_size: Organization size in terms of employees (single item)

assess the PLS path model's predictive accuracy through a blindfolding procedure (Rigdon, 2014; Stone, 1974). In line with the thumb rule, the $Q^{2}$ values show the medium predictive relevance of our PLS-path model (Hair, Risher, Sarstedt, \& Ringle, 2019). Further, to assess the model's predictive power, the PLS-predict assessment method was used which calculates the mean absolute errors (MAE) and root mean squared error (RMSE) (Shmueli et al., 2019). As per guidelines provided by Shmueli et al. (2019), we compared the values of MAE and RMSE of PLS-SEM path model analysis with the linear regression model (LM) benchmark. The results confirm that the model has high predictive power as the values of MAE and RMSE of LM are higher than the PLS-SEM analysis (Hair, Risher, Sarstedt, \& Ringle, 2019, p. 13).

The structure model in SmartPLS provides an inner-modeling analysis of the direct and indirect association between independent, mediators and dependent variables, including $t$ values and path coefficients. The path coefficient is like the standardized beta coefficient in regression analysis (Henseler, Ringle, \& Sinkovics, 2009). For the said purpose, we followed the suggestions of Hair, Hult, Ringle, and Sarstedt (2014a), Hair, Black, Babin, and Anderson (2014b) and performed a bootstrapping method with 10,000 resampling iterations to determine the beta and $t$-values. T-value higher than 1.96 and $p$-value less than 0.05 indicate a significant relationship at a 95\% confidence interval (Hair, Hult, Ringle, and Sarstedt, 2014a; Hair, Black, Babin, and Anderson, 2014b). Table 5 illustrates the results of the structural model shown in Figure 2. The results show that TL has a positive and 


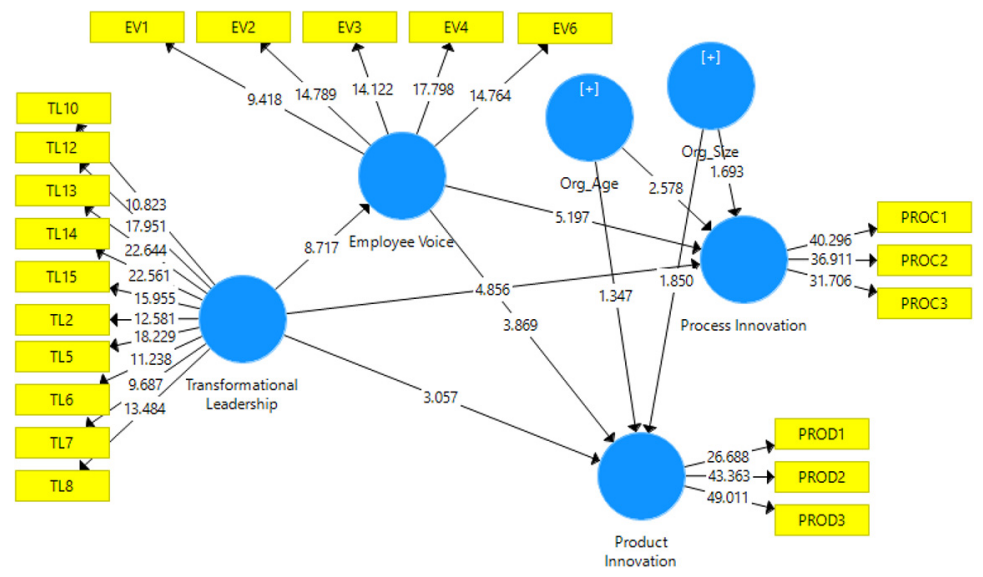

Product and
process
innovation in
SMEs

81

Figure 2.

Path analysis

statistically significant impact on product $(\beta=0.29 ; t=3.05 ; p<0.00)$ and process $(\beta=$ $0.41 ; t=4.87 ; p<0.00$ ) innovation. Organization size (control variable) relates negatively to process innovation $(\beta=-0.16 ; t=2.58 ; p<0.01)$ in the model. The findings further suggest that employee voice significantly mediates the relationship between TL and product (TL [1] $\rightarrow \mathrm{EV}[2] \rightarrow \mathrm{PROD}[3])(\beta=0.20 ; t=3.35 ; p<0.00)$ and process innovation $(\mathrm{TL} \rightarrow \mathrm{EV} \rightarrow$ PROC [4]) $(\beta=0.24 ; t=4.10 ; p<0.00)$, therefore, $H 3$ and $H 4$ are accepted. Moreover, the results suggest that the organization age (control variable) has a negative influence on the total (both direct and indirect effect) impact of transformation leadership and employee voice on process innovation $(\beta=-0.16 ; t=2.58 ; p<0.01)$.

\section{Discussion}

The objective of this study was to investigate the underlying mechanism of the relationship between TL and the innovation performance of SMEs. We hypothesized that employee voice is a potential mechanism through which transformational leaders influence the SME process and product innovation. In line with the previous literature, our findings revealed a positive but differentiating impact of TL on product innovation $(\beta=0.29)$ and process innovation $(\beta=0.41)$ in SMEs. Previous literature has generally found a positive role of TL in enhancing different innovation types (e.g. Back \& Bausch, 2018; Matzler, Schwarz, Deutinger, \& Harms, 2008; Stock \& Schnarr, 2016). However, this study takes that to the next level by identifying the varying impact of TL on different innovation types in the SME context. For instance, our findings reveal that TL has a greater influence on process innovation $(\beta=0.41)$ than product innovation $(\beta=0.29)$. This shows, through TL, is important for both innovation facets, it works better for process innovation in the SME context. This finding is consistent with the upper echelon theory (Hambrick \& Mason, 1984) assumption that SMEs' top leadership propagates and influences innovation goals both at strategic (i.e. product innovation) and operational (i.e. process innovation) levels to achieve higher performance (Hambrick, 2007).

We also found support for our novel proposition that employee voice serves as a potential mediating mechanism to link TL with two innovation types, i.e. process and product innovation. Findings confirm that TL's unique characteristics such as vision, inspirational communication, supportive behavior, intellectual stimulation and personal recognition influence employees' voice behaviors which contributes to innovation in both processes and products and services (Rafferty \& Griffin, 2004). Transformational leaders 
INMR 18,1

motivate and support employees to challenge the status quo and share new ideas and suggestions to bring improvements and innovations in process technologies and final products (Avolio \& Bass, 1995; Schmitt, Den Hartog, \& Belschak, 2016). This is consistent with prior literature which asserts that employee voice behaviors can mediate the effect of organizational contextual variables on positive organizational outcomes (Rasheed, Shahzad, Conroy, Nadeem, \& Siddique, 2017).

\section{Implications}

Scholars assert that TL has a positive impact on innovation performance (Gumusluoglu \& Ilsev, 2009; Jiang \& Chen, 2018). However, limited studies investigate the differential impact of TL on product and process innovation. Similarly, the underlying mechanisms of TL and innovation relationship still need further investigations. This study broadens our understanding of employee voice as the mechanism underlying the impact of TL on product and process innovation in SMEs. Thus, this study addressed the "black box" between TL and organizational innovation link. We extend the contemporary debate on the role of employee voice in organizational outcomes (Bashshur \& Oc, 2015) particularly in SMEs (Gilman, Raby, \& Pyman, 2015; Shahzad, Arenius, Muller, Rasheed, \& Bajwa, 2019).

This study also contributes to the upper echelon theory (Hambrick, 2007; Hambrick \& Mason, 1984) by extending its theoretical assumptions to demonstrate that TL characteristics i. e. vision, stimulation, support, communication and recognition play a significant role to promote employee voice behavior (Chen, Wang, \& Lee, 2018; Schmitt, Den Hartog, \& Belschak, 2016), which, in turn, boosts product and process innovation in SMEs (Molodchik, Jardon, \& Yachmeneva., 2020; Rasheed, Shahzad, Conroy, Nadeem, \& Siddique, 2017). By explaining how TL can help SMEs achieve innovation outcomes through employee voice, this study provides insights about innovation management frameworks in SMEs of a developing country.

The findings of this study have direct practical implications for economic and commercial impact on SMEs. Results indicate that TL encourages employee voice behavior, which in response leads to higher innovation in SMEs. Employee voice, if properly promoted and used by the leaders and SMEs, is likely to help in improving and introducing new technologies and products which will uplift innovation performance. So, SMEs must align the interests of their employees with the firm and its stakeholders to motivate them and make them feel safe in sharing their voice.

Public policy professionals can incorporate these findings to design and deliver leadership and innovation management development programs to develop SMEs' capacity to understand and adopt effective leadership styles and people management practices. SMEs all over the world and especially in the developing world struggle in innovation management because they show reluctance to adopt a leadership style that requires delegation, empowerment and participation. SMEs owners/managers consider power as an immediate reward for their entrepreneurial investment and, thus do not adopt practices that give lead or discretion to employees (Madrid-Guijarro, Garcia, \& Auken, 2009; Zhu, Wittmann, \& Peng, 2012). Due to this cynical approach, SMEs struggle to take benefits of contemporary leadership practices and employees' full potential to achieve an innovationbased advantage, which rival international firms mostly enjoy. Adoption of innovationsupportive leadership practices and employees' behaviors can potentially lead to enhanced performance and economic contribution of the SME sector.

\section{Strengths, limitations and future directions}

Some limitations of this study may provide directions for future research studies. First, this study used a cross-sectional research design to collect data from respondents. 
Future research may use a longitudinal research design to capture the transformational effects of leadership on innovation. Second, this study used a single respondent to collect data about their; immediate leader's behaviors, own voice behavior and organizational innovation, which is based on their perceptions. Future research studies may use objective measures and multiple sources to collect data. Third, this study tested the mediation role of employee voice between TL and organizational innovation, but there is a need to discover more mediating and moderating variables. Subsequent research in this intriguing area may investigate the relationship by including the moderating role of impression management or culture to see how employees' urge to maintain a good impression and organizational or national culture affects the way leadership influences voice behaviors and innovation outcomes (Tian, Deng, Zhang, \& Salmador, 2018; Wilkinson, Mowbray, \& Sun, 2018).

\section{Notes}

1. TL: Transformational leadership.

2. EV: Employee voice.

3. PROD: Product innovation.

4. PROC: Process innovation.

\section{References}

Al-Husseini, S. J., \& Dosa, T. A. (2016). The effects of transformational leadership on process innovation through knowledge sharing. International Journal of Economics and Management Engineering, 10(8), 2752-2759. https://doi.org/10.5281/zenodo.1126063

Armstrong, J. S., \& Overton, T. S. (1977). Estimating nonresponse bias in mail surveys. Journal of Marketing Research, 14(3), 396-402. https://doi.org/10.1177/002224377701400320

Atuahene-Gima, K. (1995). An exploratory analysis of the impact of market orientation on new product performance. Journal of Product Innovation Management, 12(4), 275-293. https://doi.org/ 10.1111/1540-5885.1240275

Avolio, B. J., \& Bass, B. M. (1995). Individual consideration viewed at multiple levels of analysis: A multi-level framework for examining the diffusion of transformational leadership. The Leadership Quarterly, 6(2), 199-218. https://doi.org/10.1016/1048-9843(95)90035-7

Back, P., \& Bausch, A. (2018). Not if, but how CEOs affect product innovation: A systematic review and research agenda. International Journal of Innovation and Technology Management, 16(03), 1930001 (1-52. https://doi.org/10.1142/S0219877019300015

Barney, J., Wright, M., \& Ketchen, D. J. (2001). The resource-based view of the firm: Ten years after 1991. Journal of Management, 27(6), 625-641. https://doi.org/10.1177/014920630102700601

Bashshur, M. R., \& Oc, B. (2015). When voice matters: A multilevel review of the impact of voice in organizations. Journal of Management, 41(5), 1530-1554. https://doi.org/10.1177/ 0149206314558302

Bass, B. M., \& Riggio, R. E. (2006). Transformational leadership, L. Erlbaum Associates.

Baum, J. R., Locke, E. A., \& Smith, K. G. (2001). A multidimensional model of venture growth. Academy of Management Journal, 44(2), 292-303. https://doi.org/10.5465/3069456

Chang, J., Bai, X., \& Li, J. J. (2015). The influence of leadership on product and process innovations in China: the contingent role of knowledge acquisition capability. Industrial Marketing Management, 50, 18-29. https://doi.org/10.1016/j.indmarman.2015.04.014
Product and process innovation in SMEs 
INMR

18,1

Chatzoglou, P., \& Chatzoudes, D. (2018). The role of innovation in building competitive advantages: An empirical investigation. European Journal of Innovation Management, 21(1), 44-69. https://doi. org/10.1108/EJIM-02-2017-0015

Chen, A. S.-Y., \& Hou, Y.-H. (2016). The effects of ethical leadership, voice behavior and climates for innovation on creativity: A moderated mediation examination. The Leadership Quarterly, 27(1), 1-13. https://doi.org/10.1016/j.leaqua.2015.10.007

Chen, S.-J., Wang, M.-J., \& Lee, S.-H. (2018). Transformational leadership and voice behaviors: The mediating effect of employee perceived meaningful work. Personnel Review, 47(3), 694-708. https://doi.org/10.1108/PR-01-2017-0016

Cohen, L., Manion, L., \& Morrison, K. (2013). Research methods in education, 7th ed., Routledge.

Corsi, C., \& Prencipe, A. (2018). Does CEO promote innovation in SMEs? A comparison between internal and external CEO. International Journal of Innovation Management, 23(05), 1950042 (1-19). https://doi.org/10.1142/S1363919619500427.

Cortes, A. F., \& Herrmann, P. (2019). Ceo transformational leadership and sme innovation: The mediating role of social capital and employee participation. International Journal of Innovation Management, 24(03), 2050024 (1-25). https://doi.org/10.1142/S1363919620500243.

Damanpour, F., \& Gopalakrishnan, S. (2001). The dynamics of the adoption of product and process innovations in organizations. Journal of Management Studies, 38(1), 45-65. https://doi.org/ 10.1111/1467-6486.00227

Detert, J. R., \& Burris, E. R. (2007). Leadership behavior and employee voice: Is the door really open? Academy of Management Journal, 50(4), 869-884. https://doi.org/10.5465/AMJ.2007.26279183

Duan, J., Li, C., Xu, Y., \& Wu, C. (2017). Transformational leadership and employee voice behavior: A pygmalion mechanism. Journal of Organizational Behavior, 38(5), 650-670. https://doi.org/ 10.1002/job.2157

Dunne, T. C., Aaron, J. R., McDowell, W. C., Urban, D. J., \& Geho, P. R. (2016). The impact of leadership on small business innovativeness. Journal of Business Research, 69(11), 4876-4881. https://doi. org/10.1016/j.jbusres.2016.04.046

Dyne, L. V., \& LePine, J. A. (1998). Helping and voice extra-role behaviors: Evidence of construct and predictive validity. Academy of Management Journal, 41(1), 108-119. https://doi.org/10.2307/ 256902

Ettlie, J. E., \& Reza, E. M. (1992). Organizational integration and process innovation. Academy of Management Journal, 35(4), 795-827. https://doi.org/10.5465/256316

Fernandes, R. A., Vasconcelos, R. G. S., \& Dobelin, S. (2018). Literature on organizational innovation: Past and future. Innovation \& Management Review, 15(1), 2-19. https://doi.org/10.1108/INMR01-2018-001

Fornell, C., \& Larcker, D. F. (1981). Evaluating structural equation models with unobservable variables and measurement error. Journal of Marketing Research, 18(1), 39-50. https://doi.org/10.2307/ 3151312

Forth, J., Bewley, H., \& Bryson, A. (2006). Small and medium-sized enterprises: Findings from the 2004 workplace employment relations survey, London: Department of Trade and Industry.

García-Morales, V. J., Llorens-Montes, F. J., \& Verdú-Jover, A. J. (2006). Antecedents and consequences of organizational innovation and organizational learning in entrepreneurship. Industrial Management \& Data Systems, 106(1), 21-42. https://doi.org/10.1108/02635570610642940

García-Morales, V. J., Lloréns-Montes, F. J., \& Verdú-Jover, A. J. (2007). Influence of personal mastery on organizational performance through organizational learning and innovation in large firms and SMEs. Technovation, 27(9), 547-568. https://doi.org/10.1016/j.technovation.2007.02.013

Gilman, M., Raby, S., \& Pyman, A. (2015). The contours of employee voice in SMEs: The importance of context. Human Resource Management Journal, 25(4), 563-579. https://doi.org/10.1111/17488583.12086 
Gumusluoğlu, L., \& Ilsev, A. (2009). Transformational leadership and organizational innovation: The roles of internal and external support for innovation. Journal of Product Innovation Management, 26(3), 264-277. https://doi.org/10.1111/j.1540-5885.2009.00657.x

Gumusluoglu, L., \& Ilsev, A. (2009). Transformational leadership, creativity, and organizational innovation. Journal of Business Research, 62(4), 461-473. https://doi.org/10.1016/j. jbusres.2007.07.032

Hair, J. F., Hult, G. T. M., Ringle, C. M., \& Sarstedt, M. (2014a). A primer on partial least squares structural equations modeling (PLS-SEM, SAGE.

Hair, J. F., Black, W. C., Babin, B. J., \& Anderson, R. E. (2014b). Multivariate data analysis, 7th ed., Pearson Education Limited.

Hair, J. F., Risher, J. J., Sarstedt, M., \& Ringle, C. M. (2019). When to use and how to report the results of PLS-SEM. European Business Review, 31(1), 2-24. https://doi.org/10.1108/EBR-11-2018-0203

Hambrick, D. C. (2007). Upper echelons theory: An update. Academy of Management Review, 32(2), 334-343. https://doi.org/10.5465/amr.2007.24345254

Hambrick, D. C., \& Mason, P. A. (1984). Upper echelons: The organization as a reflection of its top managers. Academy of Management Review, 9(2), 193-206. https://doi.org/10.5465/ amr.1984.4277628

Harney, B., \& Dundon, T. (2006). Capturing complexity: Developing an integrated approach to analysing HRM in SMEs. Human Resource Management Journal, 16(1), 48-73. https://doi.org/ 10.1111/j.1748-8583.2006.00004.x

Henseler, J., Ringle, C. M., \& Sarstedt, M. (2015). A new criterion for assessing discriminant validity in variance-based structural equation modeling. Journal of the Academy of Marketing Science, 43(1), 115-135. https://doi.org/10.1007/s11747-014-0403-8

Henseler, J., Ringle, C. M., \& Sinkovics, R. R. (2009). The use of partial least squares path modeling in international marketing. In R. R. Sinkovics, \& P. N. Ghauri, (Eds.), Advances in international marketing, Vol. 20, (pp. 277-319). Emerald Group Publishing Limited.

Hervas-Oliver, J.-L., Sempere-Ripoll, F., \& Boronat-Moll, C. (2014). Process innovation strategy in SMEs, organizational innovation and performance: A misleading debate? Small Business Economics, 43(4), 873-886. https://doi.org/10.1007/s11187-014-9567-3

Hitt, M. A., Keats, B. W., \& DeMarie, S. M. (1998). Navigating in the new competitive landscape: Building strategic flexibility and competitive advantage in the 21st century. Academy of Management Perspectives, 12(4), 22-42. https://doi.org/10.5465/ame.1998.1333922

Hofstede, G. (1984). Culture's consequences: International differences in work-related values, Sage.

Hullova, D., Trott, P., \& Simms, C. D. (2016). Uncovering the reciprocal complementarity between product and process innovation. Research Policy, 45(5), 929-940. https://doi.org/10.1016/j. respol.2016.01.012

Jiang, Y., \& Chen, C. C. (2018). Integrating knowledge activities for team innovation: Effects of transformational leadership. Journal of Management, 44(5), 1819-1847. https://doi.org/10.1177/ 0149206316628641

Jiménez-Jiménez, D., \& Sanz-Valle, R. (2008). Could HRM support organizational innovation? The International Journal of Human Resource Management, 19(7), 1208-1221. https://doi.org/ $10.1080 / 09585190802109952$

Jung, D. I., Chow, C., \& Wu, A. (2003). The role of transformational leadership in enhancing organizational innovation: Hypotheses and some preliminary findings. The Leadership Quarterly, 14(4-5), 525-544. https://doi.org/10.1016/S1048-9843(03)00050-X

Keupp, M. M., Palmié, M., \& Gassmann, O. (2012). The strategic management of innovation: A systematic review and paths for future research. International Journal of Management Reviews, 14(4), 367-390. https://doi.org/10.1111/j.1468-2370.2011.00321.x 
INMR 18,1

Knezović, E., \& Drkić, A. (2020). Innovative work behavior in SMEs: The role of transformational leadership. Employee Relations: The International Journal. https:/doi.org/10.1108/ER-03-2020-0124

Liaw, Y.-J., Chi, N.-W., \& Chuang, A. (2010). Examining the mechanisms linking transformational leadership, employee customer orientation, and service performance: The mediating roles of perceived supervisor and coworker support. Journal of Business and Psychology, 25(3), 477-492. https://doi.org/10.1007/s10869-009-9145-x

Love, J. H., \& Roper, S. (2015). SME innovation, exporting and growth: A review of existing evidence. International Small Business Journal: Researching Entrepreneurship, 33(1), 28-48. https://doi. org/10.1177/0266242614550190

Lowe, K. B., Kroeck, K. G., \& Sivasubramaniam, N. (1996). Effectiveness correlates of transformational and transactional leadership: A meta-analytic review of the mlq literature. The Leadership Quarterly, 7(3), 385-425. https://doi.org/10.1016/S1048-9843(96)90027-2

McDowell, W. C., Peake, W. O., Coder, L., \& Harris, M. L. (2018). Building small firm performance through intellectual capital development: Exploring innovation as the "black box. Journal of Business Research, 88, 321-327. https://doi.org/10.1016/j.jbusres.2018.01.025

MacKenzie, S. B., Podsakoff, P. M., \& Rich, G. A. (2001). Transformational and transactional leadership and salesperson performance. Journal of the Academy of Marketing Science, 29(2), 115-134. https://doi.org/10.1177/03079459994506

Madrid-Guijarro, A., Garcia, D., \& Auken, H. V. (2009). Barriers to innovation among Spanish manufacturing SMEs. Journal of Small Business Management, 47(4), 465-488. https://doi.org/ 10.1111/j.1540-627X.2009.00279.X

March-Chordà, I., Gunasekaran, A., \& Lloria-Aramburo, B. (2002). Product development process in spanish SMEs: An empirical research. Technovation, 22(5), 301-312. https://doi.org/10.1016/ S0166-4972(01)00021-9

Matzler, K., Schwarz, E., Deutinger, N., \& Harms, R. (2008). The relationship between transformational leadership, product innovation and performancein SMEs. Journal of Small Business \& Entrepreneurship, 21(2), 139-151. https://doi.org/10.1080/08276331.2008.10593418

Molodchik, M., Jardon, C., \& Yachmeneva, E. (2020). Multilevel analysis of knowledge sources for product innovation in Russian SMEs. Eurasian Business Review. https://doi.org/10.1007/s40821020-00166-6

Murat, I. A., \& Baki, B. (2011). Antecedents and performance impacts of product versus process innovation: Empirical evidence from SMEs located in Turkish science and technology parks. European Journal of Innovation Management, 14(2), 172-206. https://doi.org/10.1108/14601061111124885

Podsakoff, P. M., MacKenzie, S. B., Lee, J.-Y., \& Podsakoff, N. P. (2003). Common method biases in behavioral research: A critical review of the literature and recommended remedies. Journal of Applied Psychology, 88(5), 879-903. https://doi.org/10.1037/0021-9010.88.5.879

Podsakoff, P. M., \& Organ, D. W. (1986). Self-reports in organizational research: Problems and prospects. Journal of Management, 12(4), 531-544. https://doi.org/10.1177/014920638601200408

Porter, M. E. (1990). New global strategies for competitive advantage. Planning Review, 18(3). https:// doi.org/10.1108/eb054287

Rafferty, A. E., \& Griffin, M. A. (2004). Dimensions of transformational leadership: Conceptual and empirical extensions. The Leadership Quarterly, 15(3), 329-354. https://doi.org/10.1016/j. leaqua.2004.02.009

Rasheed, M. A., Shahzad, K., Conroy, C., Nadeem, S., \& Siddique, M. U. (2017). Exploring the role of employee voice between high-performance work system and organizational innovation in small and medium enterprises. Journal of Small Business and Enterprise Development, 24(4), 670-688. https://doi.org/10.1108/JSBED-11-2016-0185

Rigdon, E. E. (2014). Rethinking partial least squares path modeling: Breaking chains and forging ahead. Long Range Planning, 47(3), 161-167. https://doi.org/10.1016/j.lrp.2014.02.003 
Rodríguez-Ardura, I., Meseguer-Artola, A., Rodríguez-Ardura, I., \& Meseguer-Artola, A. (2020). Editorial: How to prevent, detect and control common method variance in electronic commerce research. Journal of Theoretical and Applied Electronic Commerce Research, 15(2). https://doi. org/10.4067/S0718-18762020000200101

Rosca, E., \& Bendul, J. C. (2019). Value chain integration of base of the pyramid consumers: An empirical study of drivers and performance outcomes. International Business Review, 28(1), 162176. https://doi.org/10.1016/j.ibusrev.2018.05.009

Sameer, M., \& Özbilgin, M. F. (2014). 25 Employee voice in the SME context. Handbook of research on

Product and process innovation in SMEs employee voice, (pp. 410-420). Northhampton, MA: Elgar Publishing.

Sattayaraksa, T., \& Boon-Itt, S. (2016). CEO transformational leadership and the new product development process: The mediating roles of organizational learning and innovation culture. Leadership \& Organization Development Journal, 37(6), 730-749. https://doi.org/10.1108/LODJ10-2014-0197

Schmitt, A., Den Hartog, D. N., \& Belschak, F. D. (2016). Transformational leadership and proactive work behaviour: A moderated mediation model including work engagement and job strain. Journal of Occupational and Organizational Psychology, 89(3), 588-610. https://doi.org/10.1111/ joop. 12143

Selvaraj, P., \& Joseph, J. (2020). Employee voice implications for innovation in a deliberative environment context of Indian organizations. Personnel Review, 49(7). https://doi.org/10.1108/ PR-11-2019-0601

Sethibe, T. G. (2018). Towards a comprehensive model on the relationship between leadership styles, organisational climate, innovation and organisational performance, 1850021 (1-19), International Journal of Innovation Management, 22(2). https://doi.org/10.1142/S1363919618500214.

Shahzad, K., Arenius, P., Muller, A., Rasheed, M. A., \& Bajwa, S. U. (2019). Unpacking the relationship between high-performance work systems and innovation performance in SMEs. Personnel Review, 48(4), 977-1000. https://doi.org/10.1108/PR-10-2016-0271

Shmueli, G., Sarstedt, M., Hair, J. F., Cheah, J.-H., Ting, H., Vaithilingam, S., \& Ringle, C. M. (2019). Predictive model assessment in PLS-SEM: Guidelines for using PLSpredict. European Journal of Marketing, 53(11), 2322-2347. https://doi.org/10.1108/EJM-02-2019-0189

Siqueira, A. C. O., \& Cosh, A. D. (2008). Effects of product innovation and organisational capabilities on competitive advantage: Evidence from UK small and medium manufacturing enterprises. International Journal of Innovation Management, 12(2), 113-137. https://doi.org/10.1142/ S1363919608001972

SMEDA. (2007). SME policy 2007 (SME led economic growth - Creating jobs and reducing poverty). small and medium enterprise development authority, ministry of industries, production \& special initiatives, government of Pakistan. Retrieved from www.smeda.org/files/ smepolicy2007.pdf.

Snihur, Y., \& Wiklund, J. (2019). Searching for innovation: Product, process, and business model innovations and search behavior in established firms. Long Range Planning, 52(3), 305-325. https://doi.org/10.1016/j.lrp.2018.05.003

Stock, R. M., \& Schnarr, N. L. (2016). Exploring the product innovation outcomes of corporate culture and executive leadership. International Journal of Innovation Management, 20(01), 1650009 (1-33), https://doi.org/10.1142/S1363919616500092.

Stone, M. (1974). Cross-Validatory choice and assessment of statistical predictions. Journal of the Royal Statistical Society: Series B (Methodological), 36(2), 111-133. https://doi.org/10.1111/j.25176161.1974.tb00994.x

Svendsen, M., \& Joensson, T. S. (2016). Transformational leadership and change related voice behavior. Leadership \& Organization Development Journal, 37(3), 357-368. https://doi.org/10.1108/LODJ07-2014-0124 
INMR

18,1

Tarigan, Z. J. H. (2018). The impact of organization commitment to process and product innovation in improving operational performance. International Journal of Business and Society, 19(2), 335-346.

Tian, M., Deng, P., Zhang, Y., \& Salmador, M. P. (2018). How does culture influence innovation? A systematic literature review. Management Decision, 56(5), 1088-1107. https://doi.org/10.1108/ MD-05-2017-0462

Tipu, S. A. A., Ryan, J. C., \& Fantazy, K. A. (2012). Transformational leadership in Pakistan: An examination of the relationship of transformational leadership to organizational culture and innovation propensity. Journal of Management \& Organization, 18(4), 461-480. https://doi.org/ 10.1017/S1833367200000705

Wilkinson, A., Dundon, T., \& Grugulis, I. (2007). Information but not consultation: Exploring employee involvement in SMEs. The International Journal of Human Resource Management, 18(7), 1279-1297. https://doi.org/10.1080/09585190701393798

Wilkinson, A., \& Fay, C. (2011). New times for employee voice? Human Resource Management, 50(1), 65-74. https://doi.org/10.1002/hrm.20411

Wilkinson, A., Mowbray, P., \& Sun, J. J.-M. (2018). Employee voice in the Asia pacific. Asia Pacific Journal of Human Resources. https://doi.org/10.1111/1744-7941.12185

Willard, G. E., Krueger, D. A., \& Feeser, H. R. (1992). in order to grow, must the founder go: A comparison of performance between founder and non-founder managed high-growth manufacturing firms. Journal of Business Venturing, 7(3), 181-194. https://doi.org/10.1016/08839026(92)90025-M

Zhou, K. Z., \& Wu, F. (2010). Technological capability, strategic flexibility, and product innovation. Strategic Management Journal, 31(5), 547-561. https://doi.org/10.1002/smj.830

Zhu, Y., Wittmann, X., \& Peng, M. W. (2012). Institution-based barriers to innovation in SMEs in China. Asia Pacific Journal of Management, 29(4), 1131-1142. https://doi.org/10.1007/s10490-011-9263-7

\section{Appendix}

\section{Research instrument}

(1) Transformational leadership (Rafferty \& Griffin, 2004)

- Has a clear understanding of where we are going.*

- Has a clear sense of where he/she wants our unit to be in 5 years.

- Has no idea where the organization is going $(\mathrm{R})$. *

- Says things that make employees proud to be a part of this organization. *

- Says positive things about the work unit.

- Encourages people to see changing environments as situations full of opportunities.

- Challenges me to think about old problems in new ways.

- Has ideas that have forced me to rethink some things that I have never questioned before.

- Has challenged me to rethink some of my basic assumptions about my work. *

- Considers my personal feelings before acting.

- Behaves in a manner, which is thoughtful of my personal needs. *

- Sees that the interests of employees are given due consideration.

- Commends me when I do better than the average job.

- Acknowledges improvement in my quality of work.

- Personally compliments me when I do outstanding work. 
(2) Employee voice (Dyne \& LePine, 1998)

- This particular co-worker develops and makes recommendations concerning issues that affect this workgroup.

- This particular co-worker speaks up and encourages others in this group to get involved in issues that affect the group.

- This particular co-worker communicates his/her opinions about work issues to others in this group even if his/her opinion is different and others in the group disagree with him/her.

- This particular co-worker keeps well informed about issues where his/her opinion might be useful to this workgroup.

- This particular co-worker gets involved in issues that affect the quality of work-life here in this group. *

- This particular co-worker speaks up in this group with ideas for new projects or changes in procedures

(3) Product innovation (Jiménez-Jiménez \& Sanz-Valle, 2008)

- Number of new products/services introduced.

- Pioneer disposition to introduce new products/services.

- R\&D expenditure in new products/services.

(4) Process innovation (Jiménez-Jiménez \& Sanz-Valle, 2008)

- Number of changes in the process introduced.

- Pioneer disposition to introduce a new process.

- Efforts on innovation in terms of hours/person, teams and training involved in innovation.

* The items dropped during factor analysis.

\section{Corresponding author}

Muhammad Athar Rasheed can be contacted at: atharkotla@gmail.com

For instructions on how to order reprints of this article, please visit our website: 